\title{
SOCIAL ECONOMIC DETERMINANTS OF HIV STATUS IN KEBUMEN DISTRICT COMMUNITY
}

\author{
Tri Subaeti'), Argyo Demartoto'), Bhisma Murti') \\ 1) Masters Program in Public Health, Universitas Sebelas Maret \\ 2) Study Program in Sociology, Faculty of Social and Political Sciences, \\ Universitas Sebelas Maret
}

\begin{abstract}
Background: Globally, the number of people infected with Human Immunodeficiency Virus (HIV) was estimated at 36.7 million. This study aimed to examine the social economic determinants of HIV statusin Kebumen district community.

Subjects and Method: This was an analytic observational with a case-control design. This study was conducted in Kebumen District, Central Java, from January to February 2018. A sample of 81 HIV positive cases and 162 negative controls were selected for this study by fixed disease sampling. The dependent variable was HIV status. The independent variables were age, sex, marital status, income, education, ignorance of the HIV status, health worker support, number of sexual partners, and sexual transmitted infection (STI). Data on HIV status were taken from medical record. The data of other variables were collected by questionnaire. The data were analyzed by logistic regression.

Results: HIV positive status increased with higher income $(\mathrm{OR}=2.94 ; 95 \% \mathrm{CI}=$ 1.04 to $8.26 ; \mathrm{p}=0.041)$, age $\geq 24$ years $(\mathrm{OR}=4.33 ; 95 \% \mathrm{CI}=1.19$ to $15.8 ; \mathrm{p}=$ 0.026), ignorance of HIV status (OR=0.21; 95\% CI=0.09 to $0.51 ; \mathrm{p}=0.001)$, lack of health worker support $(\mathrm{OR}=5.62 ; 95 \% \mathrm{CI}=0.88$ to $35.58 ; \mathrm{p}=0.067)$, multiple sexual partner $(\mathrm{OR}=6.59 ; 95 \% \mathrm{CI}=2.69$ to $16.18 ; \mathrm{p}<0.001)$, and presence of STI $(\mathrm{OR}=14.19 ; 95 \% \mathrm{CI}=5.06$ to $39.85 ; \mathrm{p}<0.001)$.

Conclusion: HIV positive status increases with higher income, age $\geq 24$ years, ignorance of HIV status, lack of health personnel support, multiple sexual partner, and presence of STI.
\end{abstract}

Keywords: socioeconomic, determinant, HIV

\section{Correspondence:}

Tri Subaeti. Masters Program in Public Health, Universitas Sebelas Maret, Jl. Ir. Sutami 36 A, Surakarta, Indonesia. Email: etisoegito@gmail.com.

Mobile: +6281226785111 . 